\title{
The Discourse of Qanun Aceh Number 11 Year 2018 Concerning Sharia Financial Institutions in the Economic Approach
}

\author{
Luthfiyah Trini Hastuti ${ }^{1}$, Pujiyono ${ }^{2}$, Burhanudin Harahap ${ }^{3}$ \\ ${ }^{1.2 .3}$ Universitas Sebelas Maret \\ Surakarta, Indonesia \\ luthfiyah_trini@staff.uns.ac.id
}

\begin{abstract}
This research purposes to discover about the economic point of view of the law in the Policy of Qanun Number 11 year 2018 concerning Sharia Financial Institutions in Aceh Province. This research is a prescriptive doctrinal law research. The approach used is a conceptual approach which is the researchers based on the view of experts (expert) in building arguments. In this case, the view of experts that used is the idea of Richard A. Posner as the basic to build an economic approach argumentative to the law. The data analysis technique used is qualitative. The results showed that based on the theory from Posner, the policy of the formulate of the Qanun Sharia Financial Institutions was parallel to the theory of wealth maximization (Wealth Maximization Theory) with the indicator of Article 5 which stated that the objectives of the Qanun include to; encourage increase Aceh Original Revenue; increase the access of funding and business for the community; help the increase of economic empowerment and social productivity; and help the increase of social income and welfare. According to the theory of Cost and Benefit Analysis (CBA) the policy of converting from conventional banks to Sharia banks provide benefits to Sharia banks. Meanwhile according to the theory of Behavioral of Law and Economy analyzed using three approaches namely; a positive approach, it was concluded that the implementation of the Qanun will bring positive results for banking performance improvement and public awareness in carrying out economic activities based on sharia principles will make the level of default risk decreases; the prescription approach for the implementation of the Qanun is to avoid economic activities that are incompatible with Sharia principles; the normative approach confirms the enactment of the Qanun to help increase income and welfare of the society.
\end{abstract}

Keywords- Qanun, Aceh, economic approach.

\section{INTRODUCTION}

Islamic law and Aceh are two things that cannot be separated. Historically, there have been many theories put forward by experts to trace the relationship of both. One of them was delivered by Van Den Berg through theory of reception in complex which asserts that the Muslim society in Indonesia has received the entire Islamic law as a whole. The theory which delivered is based on the results of research conducted on the people of Aceh and Gayo in Banda Aceh. [1] Interaction that has long been carried out by the Aceh people with Islamic law resulted in demands that are constitutionally accommodated in
Law Number 18 Year 2001 concerning Special Autonomy for the Province of Nanggroe Aceh Darussalam.

The process of implementing Sharia in Aceh Province which has been executed since 2001 continues to experience the struggles amid the perceptions of many parties who agree and disagree with the implementation of it. There are views that support rest on several reasons. The first, historically Aceh has long applied the Islamic law, because it is a legal system that is appropriate with the history and traditions of Aceh people. Second, one way to resolve conflicts that occur in Aceh is by applying Islamic law. Third, it represents the wishes of the people of Aceh. Fourth, the implementation of Islamic law is expected to overcome moral decadence such as the practice of corruption, collusion and nepotism. While those who oppose rely on several reasons; first, the implementation of Islamic Sharia is a step of formalism in Islamic law that will not bring a successful. Second, it is considered merely a symbolic practice that is not sufficient to solve the existing problems in Aceh. Otherwise, the problem solving should be done through socio-economic and society empowerment. Third, the implementation of Islamic law in Aceh is more focused on women issues, the veil obligation, and restrictions on women's clothing. [2]

Apart from the controversy over the implementation of Islamic Sharia in Aceh, it is need to conduct the journey measure effort of the implementation of Islamic Sharia in Aceh through various approaches. One of them is by using an economic approach as done in this paper. The principle of the economic study of law is a multidisciplinary approach. Among of them were introduced by Posner in his book entitled economic analysis of law. "Economic Analysis of Law is a response to the need for these courses for a systematic presentation of economic analysis and an assessment of the economic impact of legal doctrines. [3]

Economic analysis of the law is a response of necessity to present a systematic economic analysis and assessment of economic impacts to the law. Based on the book, Posner confirms that economic analysis of law is a legal analysis that uses the help of economics in expanding the legal dimension. [4] In fulfilling their needs, humans tend to prioritize economic considerations and values. 
Therefore, humans are always given the choice to get economic satisfaction or happiness which is ultimately aimed to increasing prosperity (wealth maximizing), so it can be mentioned that humans are creature which have rationality of thinking in monetary or non-monetary terms to improve their standard of living (rational maximers).[5].

In the context of the enactment of Qanun number 11 year 2018 concerning Sharia Financial Institutions in Aceh, the idea of Posner can be used as a basis for assumptions for analyzing aspects of the happiness, satisfaction, and prosperity which felt by the people living in the scope of Aceh Province after the enactment of Qanun. Furthermore, in the enactment of the Qanun, it can also be predicted through economic analysis to the law which is perceived by the Aceh people. Sanctions given by the qanun that have been determined by the local government are effective enough in an economic perspective, so that it affects a person to not violate the prohibition in the qanun. Such assumptions require satisfying answers, so that the questions of many parties about the application of Islamic Sharia in Aceh, especially the Qanun Sharia Financial Institutions and the value of benefits to the society, especially in the economic perspective can be answered.

\section{RESEARCH METHOD}

This is a doctrinal legal research that is research on the law which is conceptualized and developed on the basis of the doctrine adopted by the conceptor. [6] The nature of prescriptive research does not start with a hypothesis because the author wants to give an argument for the research that has been done. [7] The approach used is a conceptual approach which is the researchers based on the view of experts in building arguments. In this case, the view of expert that used is Richard A. Posner's opinion as a basic in building an argumentation, then the conclusions drawn is appropriate with the flow of thought that is built. The data used are secondary data in the form of primary legal materials namely regulations and secondary legal materials in the form of scientific papers (journals), books and other written sources. The data analysis technique used is qualitative. [8] The author also uses legal hermeneutics by using grammatical interpretation methods.

\section{FINDINGS AND DISCUSSION}

The legal economic analysis field has been active since the 1970s. Beginning since Bentham. [9] The task of economics is to explore the implications of the premise that humans as rational beings always want an improvement in their lives. [10] Economic analysis of the law wants to provide a new perspective and analysis instrument of the law that tends to be highly. [11] Legal economic analysis attempts to answer two basic questions about the rule of law. That is, what is the effect of the rule of law on people's behavior and the desired effect of the rule of law socially. [12]

Wealth Maximization Theory it is actually focuses on applying the principle of efficiency as a state in which resources are allocated, so the value is maximum. [13] Knowledge of microeconomic analysis of law is very relevant and important for the legal studies because the legal analysis will acquire new knowledge, which is to consider "cost and benefit ratio" In the formation of laws and law enforcement. [14] Richard Posner asserted that observing an economic perspective on the law create behavioral law or behavioral economy. [15] So in the principle, Posner conveyed that the existence of transaction costs and such components must be accommodated into positive legal rules. [16]

The enactment of the Qanun Sharia Financial Institutions is inseparable from the privileges granted to the Aceh Government to run its government based on Islamic Sharia. The Qanun substance basically wants to realize an economic system based on Islamic Sharia. So, all financial institutions operating in the Aceh region must be based on sharia principles. Sharia Financial Institutions are Institutions that carry out activities in the banking sector, non-banking sharia financial sector and other financial sectors. In its type consists of; Sharia Banks, Sharia Non-Bank Financial Institutions, and other Financial Institutions. Sharia banks include Sharia commercial banks, Sharia business units, and Sharia people's finance banks. Sharia non-bank Financial Institutions include; Sharia insurance, Sharia capital market, Sharia pension funds, Sharia venture capital, Sharia pawnshops, Sharia finance cooperatives and its kind, Sharia financial institutions, Sharia factoring, Sharia financial institutions, Sharia financial technology, and other non-Sharia financial institutions. Other financial institutions include non-formal financial institutions and non-formal pawnshops.

In measuring the application of the Qanun, it can use an economic approach as some theories are known, namely:

\section{Wealth Maximization Theory}

The theory of maximum wealth as an embodiment of economic analysis theory in the law of Posner actually focuses on the application of the principle of efficiency. Referring to the idea of Posner, the implementation of the Qanun in Aceh can be analyzed by using the theory of wealth maximization. In this case, the making of a policy strived in order to improve the welfare of the society. The making of the Qanun is inseparable from the desire to realize the equitable and prosperous for the economy of Aceh within the auspices of the Islamic Sharia as contained in item $\mathrm{c}$ of the Qanun dictum. The value of justice and prosperity to be realized is affirmed in the dictum within the framework of Islamic Sharia referring to Article 2 of Qanun Number 8 year 2014 concerning the Principles of Islamic Sharia which the one of the 
scope covers the fields muamalah (private law). Furthermore, it is also emphasized in Article 3 of the Qanun that the LKS is based on justice, trustworthiness, brotherhood, profit, transparency, independence, cooperation, convenience, openness, sustainability, and universal. Based on this principle, it is reflected in the existence of policies oriented towards increasing the prosperity of the society by presenting sharia financial institutions which the one is justice and profit.

Based on the objectives of the establishment of sharia financial institutions, policies are reflected in the aim of improving the welfare of the society, including increasing empowerment and income of the society. The basic purpose of the establishment of the Qanun should be able to bring the Aceh people to the realist conditions, not only the idealists. Serious efforts must be conduct, so the presence of the Qanun is not as expected by some parties, especially those who are counter to the implementation of Islamic Sharia in Aceh with the reason that the application of Islamic Sharia in Aceh is not merely a symbolic practice. Based on the idea of Posner, the policy of the making of the Qanun is parallel with the theory of wealth maximization (Wealth Maximization theory). However, this case needs to be proven by concrete steps taken by the local government.

\section{Cost-Benefit Analysis Theory}

Cost and Benefit Analysis (CBA) was formally developed by Alfred Marshal. CBA is a series of technical used in making the best decision by calculating all forms of estimated losses and benefits that may arise from the proposed decision to be submitted.[17] In Cost-Benefit Analysis (CBA), an act of assumption is carried out when the profit obtained is higher than the loss or costs incurred. Furthermore, legal analysis through the CBA approach becomes important things to do in order to create legal effectiveness.

The application of the Qanun Sharia Financial Institutions is a logical consequence of the Aceh Qanun Number 8 year 2014 concerning the Principles of Islamic Sharia which explicitly requires that financial institutions operating in Aceh must be implemented based on sharia principles. In this case, there is no other choice for all financial institutions except adjusting the Qanun. In the context of the approach of Cost-Benefit Analysis for practitioners financial institutions in Aceh, the one is a sharia bank, an instruction to carry out operations from conventional to sharia does indeed incur costs (cost) specifically related to institutional aspects that Sharia banks should have branch offices in an amount that is sufficient for the needs of the society, Sharia banks should also guarantee that products and assets in conventional services should also exist and be converted in sharia. The emergence of costs over the transition from conventional banks to sharia can be compared with the benefits that could potentially be obtained in the future. If the costs incurred are proportional to the benefits to be gained, then the choice to convert to a Sharia bank is the right decision. However, if the conversion from conventional banks to Sharia banks results in losses, this policy needs to be re-evaluated.

As an illustration and comparison before the stipulation of the Qanun, there was a Aceh conventional bank that was converted into a Sharia bank that had obtained the approval of the Financial Services Authority (OJK) by stipulating the Decision of the OJK Board of Commissioners Number. K.EP44 / D.03 / 2016 dated 1 September 2016 regarding Licenses Granting Concessions for Changing Conventional Commercial Business Activities into Sharia commercial banks PT Bank Aceh. The process of converting Bank Aceh into a Sharia bank can be used as a basic for justification Cost-Benefit Analysis (CBA).

Based on the results of research conducted by Talbani Farlian and Nuraidar (2017), the data obtained about Bank Aceh which after being converted to sharia experienced a good trend performance over time. These data show that it can be seen the benefits to be obtained by Aceh Sharia Bank after being converted. It can be used as a basic for the argument that the policy of converting from conventional banks to Sharia banks according to the CBA provides benefits to Sharia banks. Conditions that occur in the Aceh Sharia Bank can be used as a basis for the assumption that the process of converting conventional banks into the Sharia banks will tend to provide benefits for Sharia Financial Institutions. So it can be concluded that the implementation of the Qanun will create more potential to bring benefits than losses.

\section{Behavioral of Law and Economy Theory}

Behavior Theory predicts a behavior of person in response to incentives or benefits. Prediction of this behavior becomes one of the considerations in determining law or policy. [18] In general, there are 3 (three) functions of the behavioral approach in economic analysis, namely: [19]

\section{a. Positive}

In a positive function, economic analysis explains the content and consequences of law. This is the core of economic analysis, for example the impact / effect of law on changes in human behavior. The legal consequences that arise with the Qanun have an impact on financial institutions in Aceh including Sharia banks. In the presence of this Qanun, all conventional bank operations must be converted into the sharia system. The behavior patterns of the society also experienced a change from the previous choice of using conventional 
banks and Sharia banks, with the existence of Qanun, the society is only faced with one Sharia financial service.

Based on the results of research conducted by Sinathrya Al Kautsar et al (2019) of Aceh Bank that was converted to Aceh Sharia Bank obtained data that the results of the conversion to Sharia banks indicates changes in the level of risk in sharia better than becoming a conventional Aceh Bank. There is a significant effect of the conversion results from Conventional Banks to Sharia Banks. The NPF / L declines when Aceh bank experiences a conversion that sharia bank, customers are more religious than conventional banks so the risk of default is decreased. The policy of Aceh to convert banking into sharia can be applied to other conventional banks because based on the case study the Aceh bank provides positive results on the level of bankruptcy risk in carrying out the sharia business model. Aceh is one of the areas which the majority of the people are holding to Islamic faith, so that the application of sharia in the banking system can work well. After the conversion, Aceh Bank looks better so it can be used as an illustration for other banks that a positive thing is exist within the conversion of sharia in Aceh to the banking business. [20]

The results of research conducted at Aceh Bank can be used as an illustration of the possibility that will occur at other banks in Aceh that will also be converted to sharia. The performance trend of Aceh Bank that continues to increase after being converted to sharia at least more promising for banking players, that the implementation of the Qanun will bring positive results for improving banking performance. Besides that, with the awareness of the society in carrying out economic activities based on sharia principles as instructed in Islam and implemented in the Qanun, the level of default risk will decrease. This case will correlate to the performance of Sharia banking in Aceh.

\section{b. Prescriptive}

The prescriptive function of economic analysis of laws and policies is to produce certain purpose such as reducing bad behavior in society. Behavioral economic approach (behavioral economics) can increase the success of recommendations (prescriptions) in compiling laws and policies. The prescription for the implementation of the Qanun is to avoid economic activities that are incompatible with Sharia principles. One of them relates to the use of financial services that contain elements of usury.

According to sharia law, usury is something that should be avoided in economic activity. Interest-based financial institutions activities (interest) strongly suspected containing the elements of usury which are prohibited, so the making of Sharia financial institutions is highly essential. Through the Qanun, the Aceh government seeks to create an usury-free economic order for the majority of Aceh's Moslem society
Accordingly, it is stated in Article 6 the Qanun Sharia Financial Institutions applies to: (a) Every Muslim person residing in Aceh or a legal entity conducting financial transactions in Aceh; (b) Any person who are not a Muslim make a transaction in Aceh can follow this Qanun; (c) Every non-Muslim person, business entity and / or legal entity conducting financial transactions with the Government of Aceh and the Government of Regency / City. This article hows clearly about the efforts of the Aceh government to create an usury-free economic order for the Aceh people. The efforts to change the economic behavior of the Aceh people are expected to be able to realize the Islamic economy of Aceh as stated in Article 5 letter (a) Qanun. The existence of an economic order that is free from the element of usury is expected that it will eliminate the element of injustice in the economic activities inherent in the ribawi institutions. The interest-based ribawi regulation that has been used by conventional financial institutions would be eliminated from the economic structure of the Aceh people.

\section{c. Normative}

Normative function of the behavioral economic approach has a comprehensive and general purpose which is to produce a policy or law that can realize a social welfare. According to Article 5 of the Qanun, it is emphasized that one of the objectives of the sharia financial institutions is to support increase the income and welfare of the society. Article 14 paragraph (3) also states that "Sharia banks are required to implement arrangements regarding the achievement of the ratio of financing to micro, small and medium enterprises in the context of increasing the economic development of the Aceh people". This case confirms that the efforts conducted by lawmakers have taken into consideration the welfare aspects that would be realized for the Aceh people, including moving the micro business sector, especially related to access to finance and capital. Furthermore, paragraph (4) states that "the financing ratio referred to the paragraph (3) shall be determined in stages as following: (a) a minimum of $30 \%$ (thirty percent) no later than 2020; (b) a minimum of $40 \%$ (forty percent) no later than 2022 ".

Obligations set for Sharia banks to achieve financing ratios for micro, small and medium businesses indicate a policy oriented towards improving the welfare of society. This can be explicitly seen from the obligations of Sharia banks to achieve the financing ratio at MSMEs. As known that Indonesia's economic sector is mostly driven by MSMEs. According to data reported by the Ministry of Cooperatives and Small and Medium Enterprises (Kemenkop UKM) reported that in terms of number of units, MSMEs have a share around $99.99 \%$ (62.9 million units) of the total number of business operators in Indonesia, while large businesses are only $0,01 \%$ or around 5400 units. Micro businesses absorb around 107.2 million labor (89.2\%). Small businesses 5.7 million (4.74\%), and Medium Enterprises 3.73 
million (3.11\%). While, large businesses absorb around 3.58 million people. This means that combined MSMEs absorb around $97 \%$ of the national workforce. While, large enterprises only absorb around $3 \%$ of the total national workforce. [21] This data shows the large role of MSMEs in moving the wheels of the national economy. The financing ratio specified in the Qanun is expected that it will facilitate MSME players in accessing capital. The perceived impact of this case will create an increasingly stretched the economy of Aceh people and will indirectly improve the welfare of the society. So, based on the normative analysis, the making of the Qanun as a policy has been oriented towards efforts to improve the aspects of society welfare, especially in the Aceh region.

The concept of welfare in Islam must be understood not only oriented towards the fulfillment of material needs alone. This is as stated by Al-Ghazali who constructs true welfare is the fulfillment of spiritual and material needs.[22] Man can be said to be prosperous when his basic needs have been materially fulfilled. In addition, humans are said to be prosperous if their needs can be fulfilled spiritually. Because humans in addition to having the material world of man also have an inner world that must be fulfilled simultaneously.[23] Ghazali further proposed the concept of maslahah in property to achieve equitable (social) well-being. Because the role and function of property is actually a means to meet human needs while also to realize equitable economic welfare and stability.

Socio-economic justice and equitable distribution of income and wealth are inseparable Islamic moral philosophies. It is based on a clear commitment to the brotherhood of humanity.[24] So that efforts to realize social justice for society run together with income equality.To realize equal rights based on morality requires fundamental change.[25]

The enactment of Qanun Sharia Financial Institutions can be seen as a fundamental change that has a significant impact on the economy of Acehnese people. Changes in the islamic-oriented financial system are applied to all financial institutions on a broad scale. This is done to realize the ideals of forming a prosperous society based on the principle of equal rights. Every society has the same right to welfare. Poverty and social inequality are often the result of economic policies oriented to a secular perspective. The enactment Qanun as an effort to make religion as a basic principle in the economy of the community. Changes in the islamic-oriented financial system are applied to all financial institutions on a broad scale. This is done to realize the ideals of forming a prosperous society based on the principle of equal rights. Every society has the same right to welfare.

Poverty and social inequality are often the result of economic policies oriented to a secular perspective.[26]
The move to restore the role of religion as the basis for man in meeting his needs. It is based on the belief that Islam is the truth, that it is a way of life that governs economic behavior, social structure, morality, and philosophy. Economic activity is part of the reflection of faith in God. [27]

Acceptance of the Islamic economic system that is rationally universal has been carried out along with the growth of sharia financial institutions in various countries in the world. The notion that there is a theological pattern in Islamic economics that will develop into sectarian thought is not evident in contemporary.[28] Islamic economics continues to be widely known and even as a subject of study in Western countries. Islamic law in the field of Islamic banking has flexibility that can not only be implemented by Muslims but also non-Muslims. In fact, sharia bank customers who are not Muslim are quite high in number. [29] This reality further confirms the existence of Islamic economics as an economic system that is relevant to the development of the times.

\section{IV.CONCLUSION}

Based on the idea of Posner, the policy of the making of the Qanun Sharia Financial Institutions is parallel with the theory of wealth maximization (Wealth Maximization Theory) with indicators of Article 3 of the Qanun that the sharia financial institutions is based on justice, trust, brotherhood, profit, transparency, independence, cooperation, convenience, openness, sustainability, and universal. Article 5 states that the objectives of sharia financial institutions are to; encourage increased Aceh Original Revenue; increase access to funding and business for the society; help increase economic empowerment and society productivity; and help increase society's income and welfare. According to the theory of Cost and Benefit Analysis (CBA) the policy of converting from conventional banks to Sharia banks provide benefits to Sharia banks. The conditions that occur in the Aceh Sharia Bank can be used as a basic for the assumption that the process of converting conventional banks into the Sharia banks will tend to provide benefits (benefit) for Sharia Financial Institutions.

\section{REFERENCES}

[1] Mohammad Daud Ali, Hukum Islam, Jakarta: Raja Grafindo, 2011.

[2] Yusny Saby. "The Ulama in Aceh: A Brief Historical Survey." Studia Islamika. Vol. 8. No. 12001.

[3] Donald H. J. Herman, Review of "Economic Analysis of Law" By Richard A. Posner, Washington University Law Review, 1974.

[4] Fajar Sugianto, "Butir-butir Pemikiran dalam Sejarah Intelektual dan Perkembangan Akademik Hukum dan Ekonomi”, DIH Jurnal Ilmu Hukum,Vol. 10. No. 19, Februari 2014. 
[5] May \& Brown, Philosophy of Law The Economic Analysis of Law, UK:Wiley-Blackwell, 2010.

[6] Soetandyo Wignjosoebroto, Hukum Konsep dan Metode, Malang: Setara Press, 2013.

[7] Peter Mahmud Marzuki, Penelitian Hukum, Jakarta: Kencana Prenada Media Group, 2014.

[8] Lexy J. Moleong, Metode Penelitian Kualitatif, Jakarta: P.T Remaja Rosdakarya, 2015.

[9] Louis Kaplow and Steven Shavell, Economic Analysis of Law, Harvard Law School and National Bureau of Economic Research, Handbook of Public Economics. Volume 3. Edited by AJ Auerbach and M. Feldstein Elsevier Science B. V All rights reserved, 2002.

[10] Richard A. Posner, Economic Analysis of Law, 7th ed, New York: Aspern Publishers, 1992.

[11] Richard A. Posner, The Problems of Jurisprudence, Massachusetts: Harvard University Press, 1993.

[12] Louis Kaplow and Steven Shavell, Economic Analysis of Law, Harvard Law School and National Bureau of Economic Research, Handbook of Public Economics. Volume 3. Edited by AJ Auerbach and M. Feldstein Elsevier Science B. V All rights reserved, 2002.

[13] Richard A. Posner, Economic Analysis of Law. Ed.4, USA: Hardvard University Press, 1994.

[14] Romli Atmasasmita, Analisis Ekonomi Mikro tentang Hukum Pidana Indonesia, Jakarta: Kencana, 2017.

[15] Todd J.Zywicki dan Anthony B Sanders, Posner, Hayek, and the Economic Analysis of Law, tanpa tahun.

[16] Muhammad Rustamaji, "Menakar Pengawasan Pemberian Bantuan Hukum. Dalam Pandangan Richard A. Posner", Jurnal Rechtsvinding, Volume 2 Nomor 1, April 2013.

[17] Fajar Sugianto, Economic Approach to Law, Jakarta: Kencana, 2013.

[18] Robert Cooter \& Thomas Ulen, Law \& Economics, Boston: Pearson, 2008.

[19] Christine Jolls, Cass R. Sunstein, \& Richard Thaler, A Behavioral Approach to Law and Economics, Stanford Law Review 1471, 1998.

[20] Sinathrya Al Kautsar, Lusiana Indra, dkk, "Pengaruh Konversi Bank Konvensional Menjadi Bank Syariah Terhadap Risiko Kebangkrutan Studi Kasus Pada Bank Aceh", E-Jurnal Ekonomi dan Bisnis Universitas Udayana 8.6, 2019.

[21]http://www.ukmindonesia.id/bacaartikel/62http://kom info.go.id/content/detail/11526/kemenkop-ukm-379juta-umkm-sudah-gonline/0/sorotan_media diakses tanggal 19 juni 2020 pukul 17:04 WIB

[22] Abdur Rohman, Ekonomi Al-Ghazali Menelusuri Konsep Ekonomi Islam dalam Ihya' Ulum Ad-din, Surabaya: Bina Ilmu, 2010.

[23] M. Umer Chapra, Islam dan Tantangan Ekonomi, Edisi terjamahan dari Islam and The Economic Challenge, diterjemahkan oleh, Ikhwan Abidin Basri, Gema Insani Press atas kerjasama dengan Tazkia Institute, Jakarta: 2000.

[24] M. Umer Chapra, Sistem Moneter Islam, Jawa Tengah: PT Aqwan Media Profetika, 2018.
[25] Ali Shariati, On the Sociology of Islam, tr. by Hamid Algar. Berkeley, Bandung: Mizan Press, 1979.

[26] M. Umer Chapra, Islam dan Tantangan Ekonomi, Edisi terjamahan dari Islam and The Economic Challenge, diterjemahkan oleh, Ikhwan Abidin Basri, Gema Insani Press atas kerjasama dengan Tazkia Institute, Jakarta: 2000.

[27] Ika Yunia Fauzia, Abdul Kadir Riyadi, "New Trends in Economic Behavior: The Phenomenon of AntiUsury Movement in Indonesia”. Studia Islamika, Vol. 27, No. 3, 2020.

[28] M. Dawam Rahardjo, Arsitektur Ekonomi Islam Menuju Kesejahteraan Sosial, Bandung: Mizan, 2015.

[29] Muhammad Nur Yasin, "Dialetic of Moslem and non-Moslem in the Development of Sharia Banking in Indonesia", Journal of Indonesian Islam, Vol.10, No.1, Juni 2016. 